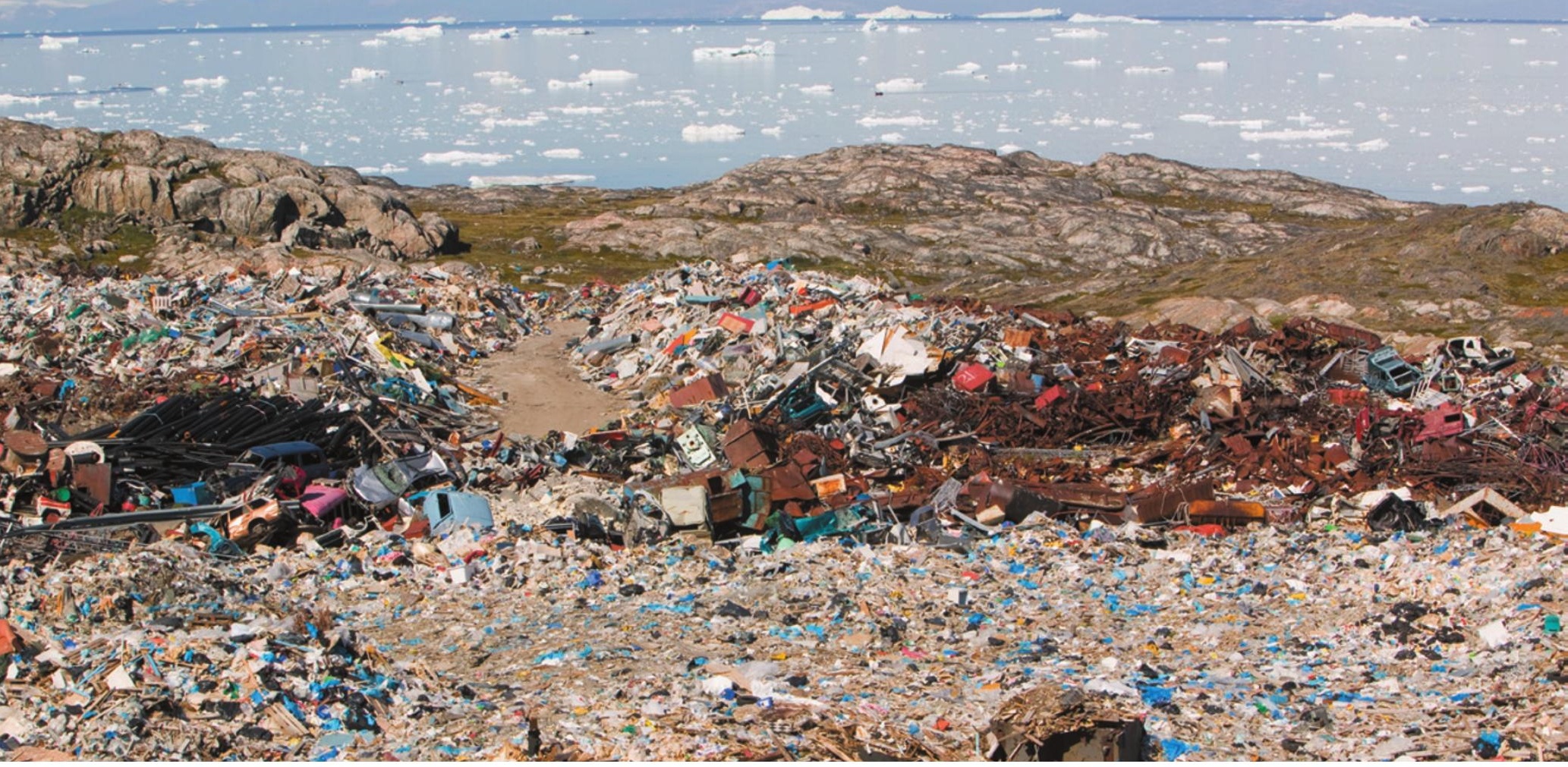

Rubbish piled up on the tundra outside Ilulissat in Greenland.

\title{
ENVIRONMENT
}

\section{Blanking out the mess}

\section{Edward Humes explores a study of the psychological dissociation plaguing our} relationship with nature.

"W hy do people make choices harmful to the environment
even when they truly care about it?" This is the deceptively simple premise of Invisible Nature, in which environmental researcher Kenneth Worthy offers psychological, cultural and philosophical explanations for our curious and contradictory relationship with nature.

It is a thought-provoking, if frustrating, exploration. Like many of us who write on the environment, Worthy has an easier time diagnosing the ailment than prescribing a plausible cure. Still, his book offers readers concerned about humanity's anaemic response to the crises of climate, waste and pollution a fresh starting point from which to consider another vital question: what next?

Worthy points to 'dissociation' as the key malady, particularly in the West. Modern economies, societies and lifestyles, he argues, put time, distance and disinformation between our everyday choices and their environmental consequences, such as acid rain caused by factory emissions. That consumer choices are destroying vital natural resources is a factor rarely experienced directly and viscerally. We roll our rubbish to the kerb and it 'magically' disappears, never requiring us to smell a refuse dump or see the accumulation of plastic in oceans. Our experience of nature is limited to curated parks and street trees. Therein, Worthy writes, lies our downfall.

He offers eye-opening illustrations of the harm enabled by dissociation. Many consumers know that the silicon 'brains' inside their beloved smartphones are produced in clean, airtight rooms by workers wearing immaculate protective suits. Few realize that those suits are designed to protect the chips, not the workers. Toxic chemicals soak through, causing myriad health problems.

In the most fascinating part of Invisible Nature, Worthy takes his enquiry in a more original direction by examining the psychology of dissociation. He draws environmental lessons from the landmark 1960s experiments of social psychologist Stanley Milgram, in which students administered what they believed were powerful electric shocks to a person in the next room when urged to do so by an authority figure, despite hearing the person's screams and pleas. The students' destructive obedience has been partly attributed to dissociation. The percentage of students willing to administer the largest shocks plummeted when they were in the same room as their victims, and fell even lower when they had to force their victims' hands against a shock plate. The tendency of people acting as agents of a trusted author-

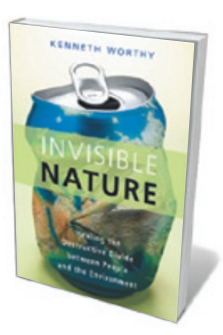

Invisible Nature: Healing the Destructive Divide Between People and the Environment

Prometheus: 2013 ity to commit acts they might never perform alone is another sort of dissociation: of action from responsibility.

Worthy contends that Milgram's results - and those of the 20 subsequent obedience experiments modelled on his work - provide a psychological explanation for why people knowingly make environmentally destructive choices. He also draws 
on the genocide studies of psychologist Ervin Staub, who suggests that psychological barriers to admitting that past acts were wrong encourage further destructive choices.

Worthy's argument begs many questions. Which variables lead to fewer destructive choices? Is detailed knowledge of environmental destruction enough, or is direct experience needed? Can trusted authority figures enforce 'constructive obedience', prodding people toward environmentally benign policies? This approach has worked in numerous communities worldwide, where consumers have abandoned disposable plastic shopping bags, urged on by civic leaders, elected officials and celebrity spokespeople. Most of all, I wanted Worthy to relate the thoughts and rationale of real people who chose a hybrid car or a gas guzzler, a reusable bag or a plastic sack. Why did they make those choices, and what would it take to alter them?

Instead, Invisible Nature switches to a lengthy, dry attack on Plato, Aristotle and Descartes as the philosophical fathers of our estrangement from nature. Oddly, these historical figures are the book's only fully developed characters. The sole modern human is Worthy's fictional character, Joe the accountant, a "typical office worker" who "spends most of his time with symbols, concepts, and figures that are abstractions of material-world things". Joe pops up now and then when the author needs a character who drinks from plastic water bottles or who is overly proud of his smartphone. But, being a caricature, he can't explain his choices - and that's too bad.

The book concludes with a disappointingly familiar list of ways to enhance our engagement with nature: cycling more; planting a vegetable garden; and embracing Eastern philosophies that depict nature and humanity in a mutually dependent context.

Invisible Nature could have been a great book had Worthy focused more on the psychology of dissociation and less on longdead philosophers. Modern thinking on marketing, globalism and consumerism is more relevant to current environmental problems than ruminations on mind-body dualism. After all, it was J. Gordon Lippincott, father of corporate branding, who in 1947 set out the axiom of modern, environmentally destructive consumerism: "Our willingness to part with something before it is completely worn out is a phenomenon noticeable in no other society in history ... It must be further nurtured even though it runs contrary to one of the oldest inbred laws of humanity, the law of thrift."

Edward Humes is a Pulitzer prizewinning journalist and the author of 12 non-fiction books. His most recent is Garbology: Our Dirty Love Affair With Trash.

\section{Books in brief}

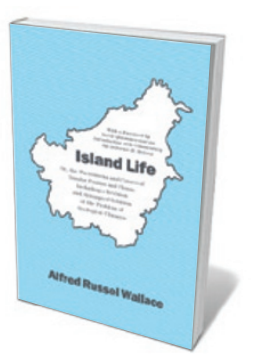

Island Life: Or, the Phenomena and Causes of Insular Faunas and Floras, Including a Revision and Attempted Solution of the Problem of Geological Climates

Alfred Russel Wallace, with Lawrence R. Heaney UNIVERSITY OF CHICAGO PRESS (2013)

Co-discoverer of natural selection Alfred Russel Wallace pioneered island biogeography — the study of how organisms are distributed on isolated land masses. In fact, he was the field's Kepler, Linnaeus and even Chuck Berry, avers David Quammen in his foreword to this facsimile of Wallace's landmark 1880 study (see also Nature 496, 165-166; 2013). Includes a commentary by Lawrence R. Heaney.

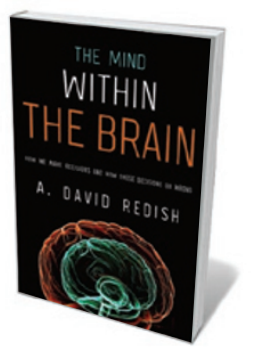

The Mind Within the Brain: How We Make Decisions and How Those Decisions Go Wrong

A. David Redish OXFORD UNIVERSITY PRESS (2013)

From drinking that fifth Martini to choosing a career, decisions shape our lives. In his study of the science of decision-making, neuroscientist David Redish keeps a cool head in an overheated theoretical arena. Synthesizing findings in psychology, robotics and more, he takes us from brain physiology to aspects of mind. His own decision-making model involves multiple 'action-selection' systems, failures in which can lead to behaviours such as compulsive gambling. Well researched and delivered with a light touch.

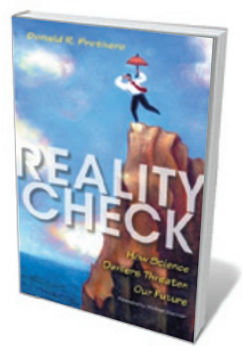

Reality Check: How Science Deniers Threaten Our Future Donald R. Prothero INDIANA UNIVERSITY PRESS (2013)

The shabby tactics of science denialists sparked this astute exposition of what we lose when science is sidelined. Palaeontologist Donald Prothero lays out key cases, such as former US President Ronald Reagan's misbegotten Strategic Defense Initiative and the demonization of biologist Rachel Carson for her work on pesticides. The usual suspects - from creationists to anti-vaccinationists - are examined too. Ultimately, Prothero argues, by claiming that clear findings on climate change, biodiversity loss and overpopulation are false, deniers inch us closer to catastrophic planetary tipping points.

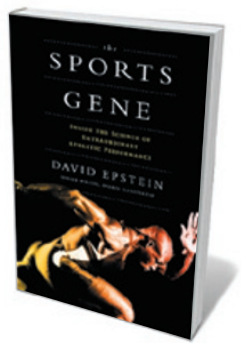

The Sports Gene: Inside the Science of Extraordinary Athletic Performance

David Epstein CURRENT (2013)

Sports-science writer David Epstein enters the nature-nurture debate on elite sporting ability. Drawing on interviews with sports scientists and leading athletes, Epstein looks at psychologist Anders Ericsson's '10,000-hour' study on how practice can masquerade as innate talent; gender testing and chromosomal anomalies; the heritability of height; and more. His conclusion that sporting excellence is down to the interplay of luck, intent and effort hardly surprises, but this is a rollicking ride through the latest science.

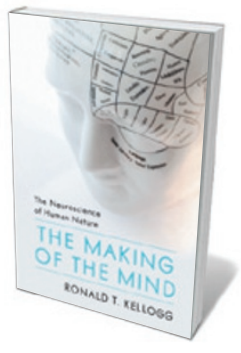

The Making of the Mind: The Neuroscience of Human Nature Ronald T. Kellogg PROMETHEUs (2013)

The genetic overlap between Homo sapiens and the chimpanzee is a biological conundrum. Some primatologists focus on what we share; cognitive psychologist Ronald Kellogg looks at what makes the human brain distinct. He argues that it is the interaction of cognitive elements such as our complex social intelligence and comprehension of others' mental intentions; symbolic thought and language; and a sense of time. Kellogg ends by speculating about the shaping of a "post-literate, Internet mind". Barbara Kiser 